\title{
Low-cost activated carbon production from organic waste and its utilization for wastewater treatment
}

\author{
Sudheer Kumar Shukla ${ }^{1}$. Noof Rashid Said Al Mushaiqri ${ }^{1}$ Hajar Mohammed Al Subhi ${ }^{1} \cdot$ Keunje Yoo $^{2}$. \\ Hafez Al Sadeq ${ }^{1}$
}

Received: 30 September 2018 / Accepted: 9 January 2020 / Published online: 25 January 2020

(c) The Author(s) 2020

\begin{abstract}
In the present study, organic waste materials, like coconut shell, orange peels, and banana peels were used to produce activated carbon. Chemical activation was carried out using phosphoric acid $\left(\mathrm{H}_{3} \mathrm{PO}_{4}\right)$. The activation temperatures were selected at the range of $200-300{ }^{\circ} \mathrm{C}$. Surface morphology of the different activated carbon derived from the different waste materials was investigated using scanning electron microscope. Pollution removal efficiency of different activated carbons was carried out by Jar test. The jar test was carried out at $120 \mathrm{rpm}$, at $20^{\circ} \mathrm{C}$ temperature for $1 \mathrm{~h}$. Three different sizes; $75 \mu \mathrm{m}, 150 \mu \mathrm{m}$ and $425 \mu \mathrm{m}$, and three concentration; $100 \mathrm{mg} / \mathrm{l}, 200 \mathrm{mg} / \mathrm{l}$ and $500 \mathrm{mg} / \mathrm{l}$ of the activated carbon were selected for the pollution removal experiments. Water quality parameters like $\mathrm{pH}$, TSS, and COD were analyzed using standard AWWA/APHA methods to know the pollution removal efficiency. COD removal varies from 48 to $99 \%$ in different activated carbon at different size and concentration. TSS removal varies from 43 to $100 \%$ by different activated carbon. The highest adsorption was observed by $75 \mu \mathrm{m}$ activated carbon. Among all the experimented materials activated carbon made from orange peels performed better than others possibly due to the formation of more $\mathrm{C}-\mathrm{O}$ and $\mathrm{C}=\mathrm{O}$ functional groups due to the presence of more carbon and oxygen elements than others. This study opens a new way of wastewater treatment in Oman by using lowcost activated carbon made from locally available organic waste and at the same time, it shall help in managing organic waste.
\end{abstract}

Keywords Activated carbon $\cdot$ Adsorbent materials $\cdot$ Coconut shell $\cdot$ Banana peels $\cdot$ Orange peels $\cdot$ Wastewater treatment

$\begin{array}{ll}\begin{array}{l}\text { Abbreviations } \\ \text { COD }\end{array} & \begin{array}{l}\text { Chemical oxygen demand } \\ \text { Total suspended solid } \\ \text { Activated carbon } \\ \text { TSS }\end{array} \\ \text { AC } & \begin{array}{l}\text { Central analytical and applied research } \\ \text { unit }\end{array} \\ \text { CAARU } & \begin{array}{l}\text { American Water Works Association/ } \\ \text { American Public Health Association }\end{array} \\ \text { AWWA/APHA } & \text { Scanning electron microscopy } \\ \text { SEM } & \text { Coconut shells activated carbon } \\ \text { CSAC } & \text { Banana peels activated carbon } \\ \text { BPAC } & \text { Orange peels activated carbon } \\ \text { OPAC } & \end{array}$

Sudheer Kumar Shukla

sudheerkrshukla@gmail.com

1 Department of Civil and Environmental Engineering, National University of Science and Technology, Muscat, Sultanate of Oman

2 Department of Earth and Environmental Engineering, Columbia University, New York 10027, USA

\section{Introduction}

The world is facing a drinking water crisis (Gupta et al. 2012) and Sultanate of Oman is not an exception. Limited viability of fresh water makes the sultanate more sensitive to the water crisis. Wastewater treatment and recycle could reduce some pressure on freshwater sources. This has forced the researchers to cost-effective and efficient wastewater treatment technology (Gupta and Ali 2013a). There are various techniques, like adsorption, membrane filtration and reverse osmosis are being used to make wastewater suitable for further use (Gupta and Ali 2013b). Adsorption using activated carbon is considered one of the most efficient and costeffective techniques (Ali and Gupta 2007; Ali et al. 2012). In a review paper, (Ali 2012) discussed various aspects of water treatment by adsorption using nanoadsorbents. High cost of coal-based activated carbon has stimulated the search for the cheapest alternatives (Abdurrahman et al. 2013; Ali 2010). Low-cost activated carbon has been the focus of research in recent years. Agricultural waste such as coconut shell (Arena et al. 2016), orange and banana peels (De Gisi et al. 2016)

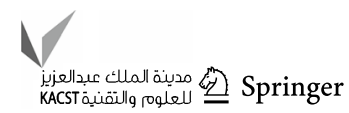


are getting much attention these days. The basic components of the agricultural waste materials include hemicelluloses, lignin, lipids, proteins, simple sugars, water, hydrocarbons, and starch, containing a variety of functional groups with a potential sorption capacity for various pollutants (Bhatnagar and Sillanpää 2010; Bhatnagar et al. 2015). Use of the waste as a low-cost adsorbent will provide two advantages, firstly, recycling of waste material and secondly economical (Grassi et al. 2012). It has already been established that the activated carbon from agriculture act as a good adsorbent for the various pollutants (Foo and Hameed 2012). After comparing chemical oxygen demand (COD) reduction efficiency of acid-activated pecan shell-based granular activated carbon with the adsorption efficiency of the commercial carbon (Bansode et al. 2004) concludes that acid-activated pecan shell-based carbons had higher adsorption for organic matter measured as COD. Specific properties of activated carbon depend not only on the raw material but also on the activation process employed, which may be conducted by physical processes (De Gisi et al. 2016). Activated carbon with a lower temperature of carbonization was exhibiting better characteristics compared with activated carbon prepared at a higher temperature of carbonization (Ashtaputrey and Ashtaputrey 2016). Phosphoric acid increases the porous structure resulting high surface and high total pore volume of carbons (Yakout and El-deen 2016). Therefore, chemical activation affects the adsorption of activated carbon and ability based on differences properties such as surface area, density, $\mathrm{pH}$, and conductivity. Though there are plenty of studies reported about activated carbon around the world, however, there is a dearth of studies in Oman. Moreover, according to the literature available, low-cost adsorbents represent a promising green technology. Potentially, they can be applied at full-scale wastewater treatment. However, there are only a few studies reported using real wastewater. Also, there is a lack of data concerning the characteristics of the adsorbents such as their average particle size or specific surface area (De Gisi et al. 2016). To fill the gap, this study is aimed to ascertain the pollution removal capacity of various activated carbons derived from waste materials generated in Oman; effects of different particle size and concentration were also studied.

\section{Materials and methods}

\section{Preparation of activated carbon}

Raw materials (coconut shell, banana peels, and orange peels) were collected from the home kitchen; $250 \mathrm{~g}$ for each material was taken, chopped into small pieces, washed with tap water and then dried under the sunlight for $24 \mathrm{~h}$. Each material was burned at different temperatures depending on their characteristic and amount. Each material was put in a metal container, and then, the containers were placed into a muffle furnace, containing material separately at the predecided temperature and time; coconut shell was burned at $300{ }^{\circ} \mathrm{C}$ for $1 \mathrm{~h}$, banana and orange peels were burnt separately at $200{ }^{\circ} \mathrm{C}$ temperature for $1 \mathrm{~h}$. As the lower temperature in the carbonization process gives a better result than high temperature (Ashtaputrey and Ashtaputrey 2016), the temperature was increased to the set level by increasing at the rate of $20^{\circ} \mathrm{C} / \mathrm{min}$ increment. After taking out the samples from the furnace, the samples were cooled for $30 \mathrm{~min}$ at room temperature, washed with distilled water; to remove dust and impurities, and dried in the oven at $105^{\circ} \mathrm{C}$ for $1 \mathrm{~h}$. Then, the samples were crushed into powder using mortar and then sieved using a sieve to remove big particles. For acid activation, three beakers of $500 \mathrm{ml}$ were taken for the three materials. The milled coconut shells, orange peels, and banana peels were separately added to the $100 \mathrm{ml}$ of concentrated phosphoric acid $\left(\mathrm{H}_{3} \mathrm{PO}_{4}\right)$ in a $500 \mathrm{ml}$ beaker, for $24 \mathrm{~h}$. This will help in increasing porosity of activated carbon at the same time increases surface area for adsorption process (Yakout and El-deen 2016). The soaked shells and peels were burned at the same temperature and time which was taken initially before for the carbonization process. Then, the samples were soaked again in $100 \mathrm{ml}$ of distilled water with $1 \mathrm{gm}$ of sodium bicarbonate for $24 \mathrm{~h}$; excess phosphoric acid was removed from the sample. Samples were then washed separately with distilled water for 4-5 times until $\mathrm{pH}$ becomes neutral. The washed samples were dried at $110^{\circ} \mathrm{C}$. The activated carbon of each material was milled and sieved to a $75 \mu \mathrm{m}, 150 \mu \mathrm{m}$ and $425 \mu \mathrm{m}$ mesh size to get a different size activated carbon. Dried and sieved samples were stored in the clean and dry container.

\section{Physical properties of AC}

Physical properties of CSAC, BPAC, and OPAC of 75 microns activated carbon, which achieved the best adsorption of all pollutant, were analyzed by scanning electron microscopy (SEM) at Central Analytical and Applied Research Unit (CAARU), Sultan Qaboos University, Oman.

\section{Pollution removal efficiency}

Nine conical flasks were taken for each material and different concentration of activated carbon, i.e., $10 \mathrm{mg}, 20 \mathrm{mg}$, $50 \mathrm{mg}$ was added into each conical flask with different size (75, 150 and 425 microns), each conical flask filled with $100 \mathrm{ml}$ of wastewater sample prior to adding activated carbon. The samples were shaken at $120 \mathrm{rpm}$, at $20^{\circ} \mathrm{C}$ for $1 \mathrm{~h}$ using Orbital Shaker. Samples were taken from the orbital shaker and left for 30 min for settling down the activated 
carbon. Then, samples were filtered using 40 grade Whatman filter paper. After filtration samples were analyzed for different water quality parameters. Water quality parameters like $\mathrm{pH}, \mathrm{COD}$ and TSS were analyzed using AWWA/APHA standard methods (Association et al. 1915).

\section{Results and discussion}

\section{Physical properties of activated carbon using SEM}

\section{Physical properties of CSAC}

As shown in (Fig. 1), CSAC has a lot of pores with different size and shapes. From the micrographs, the shape of the external surface of the activated carbons looks like a wall has cracks and some grains in various sizes in some holes. And the activated carbon morphology looks like a bone. The analysis of CSAC, shown in (Fig. 2), showed the presence of various elements along with a high amount (77.4\%) of carbon. Good activated carbon formation evident by the presence of high amount of carbon and formation of holes and rough surface which attribute to better adsorption of pollutants.

\section{Physical properties of BPAC}

Figure 3 illustrates the SEM images of banana peels activated carbons. As shown (Fig. 3), the surface looks smooth and there is a channel-like wall on the surface of raw material and pores of different size, shapes, and small grains. It can be seen from (Fig. 4) the presence of various elements with $60.8 \%$ of carbon. That is considered a good amount of carbon present in the sample.

\section{Physical properties of OPAC}

Figure 5 shows the SEM images of orange peels activated carbon. As shown (Fig. 5), the surface is smooth and there was a channel-like wall on the surface of the raw material and pores of different size and shapes also have different size of grains in the surface area. Figure 6 shows the presence of various elements with a high amount (72.9\%) of carbon. The external surface has a crack and a lot of grains particles with irregular and heterogeneous surface morphology with a well-developed porous structure. That attributes to better adsorption of pollutants.

Among activated carbon made different studied materials, activated carbon made from coconut shells have a high percentage of carbon $77.4 \%$, then activated carbon made from orange peels with $72.9 \%$ carbon, while activated carbon made from banana peels have least amount (60.8\%) of carbon. With more holes and roughness on the surface, the formation of active surface is more in the activated carbon made from coconut shells and orange peels than the activated carbon made from banana peels.
Fig. 1 Scanning electron microscopic analysis of activated carbon made from coconut shell

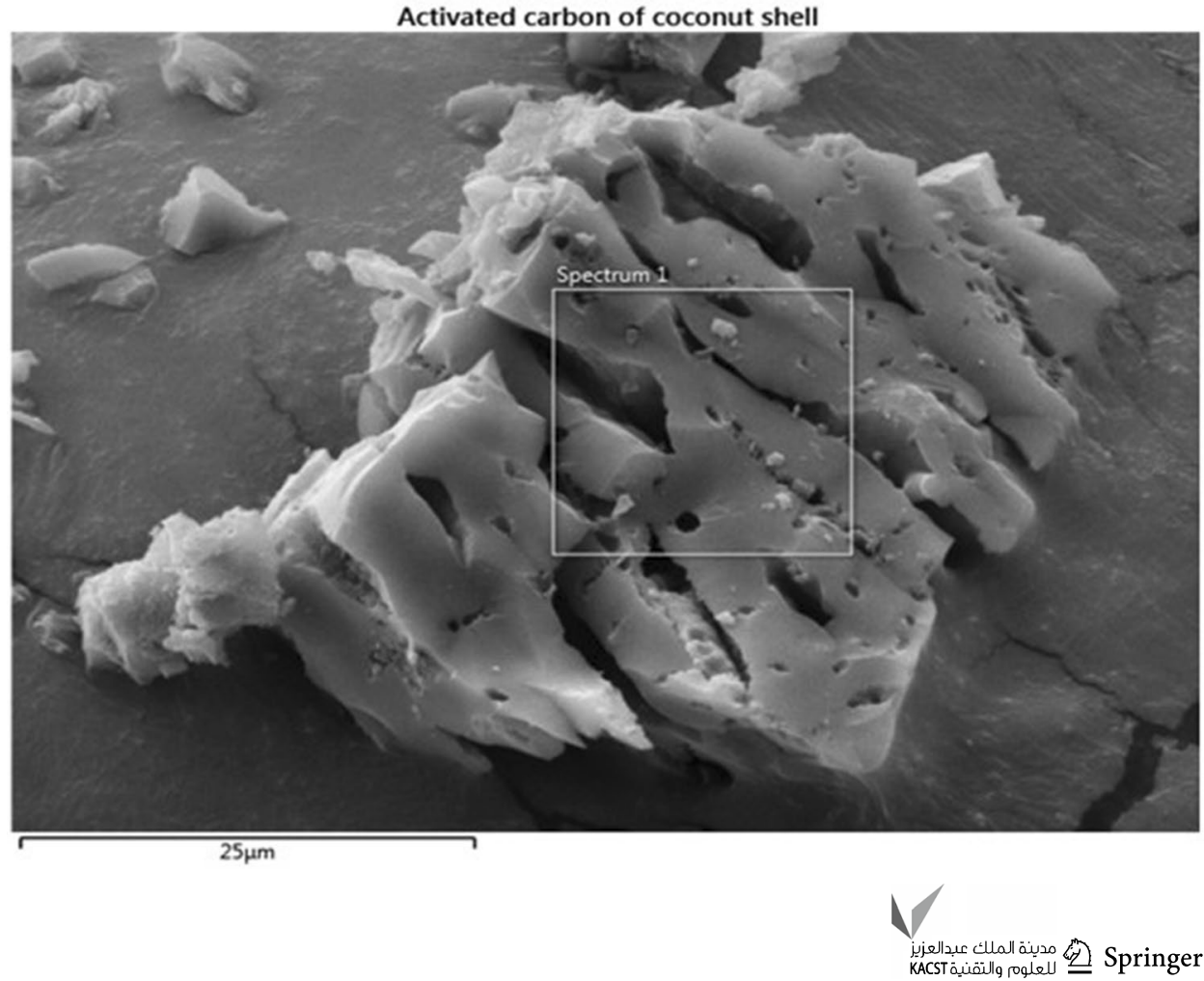




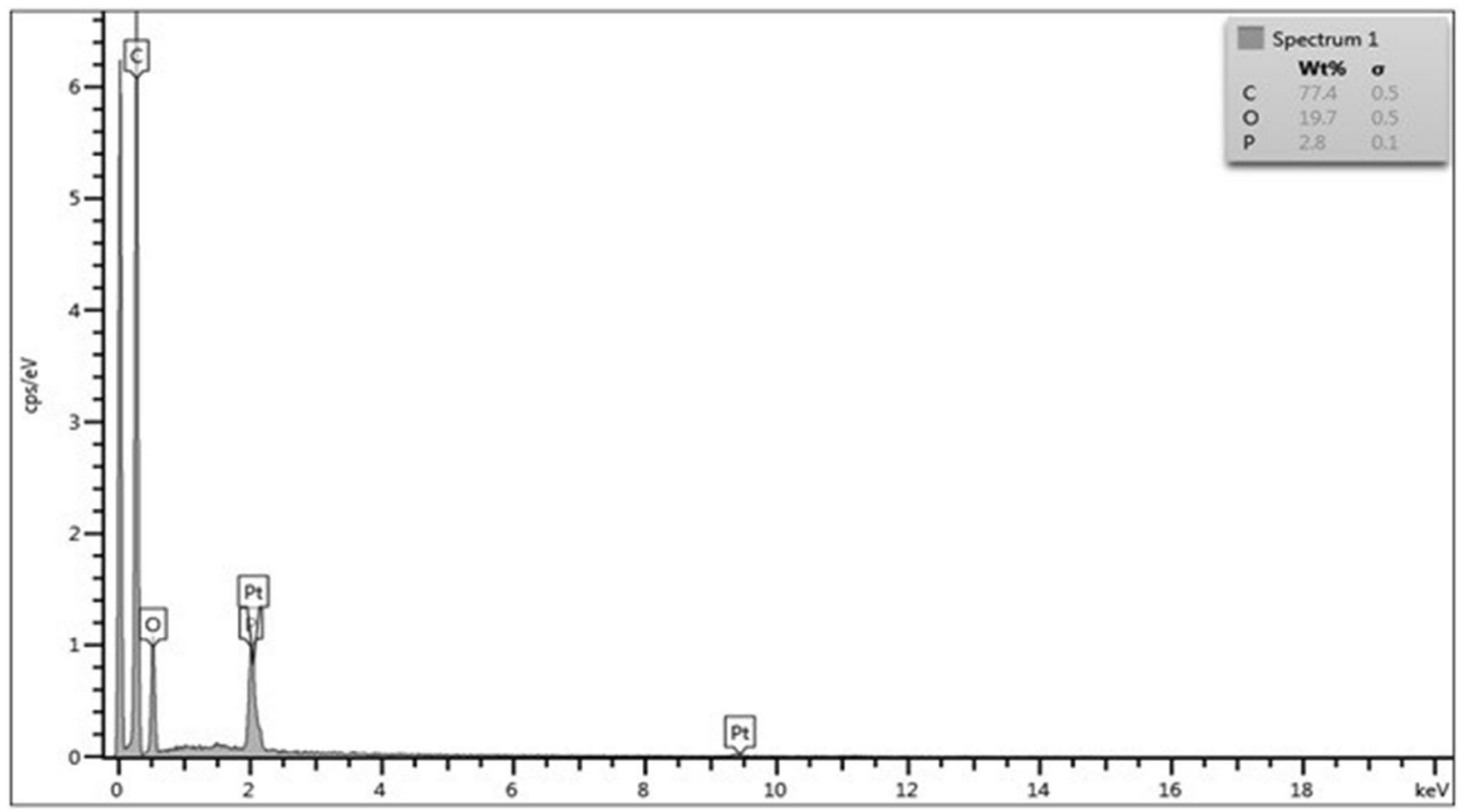

Fig. 2 Different elements observed during scanning electron microscopic analysis of activated carbon made from coconut shell

Fig. 3 Scanning electron microscopic analysis of activated carbon made from banana peels

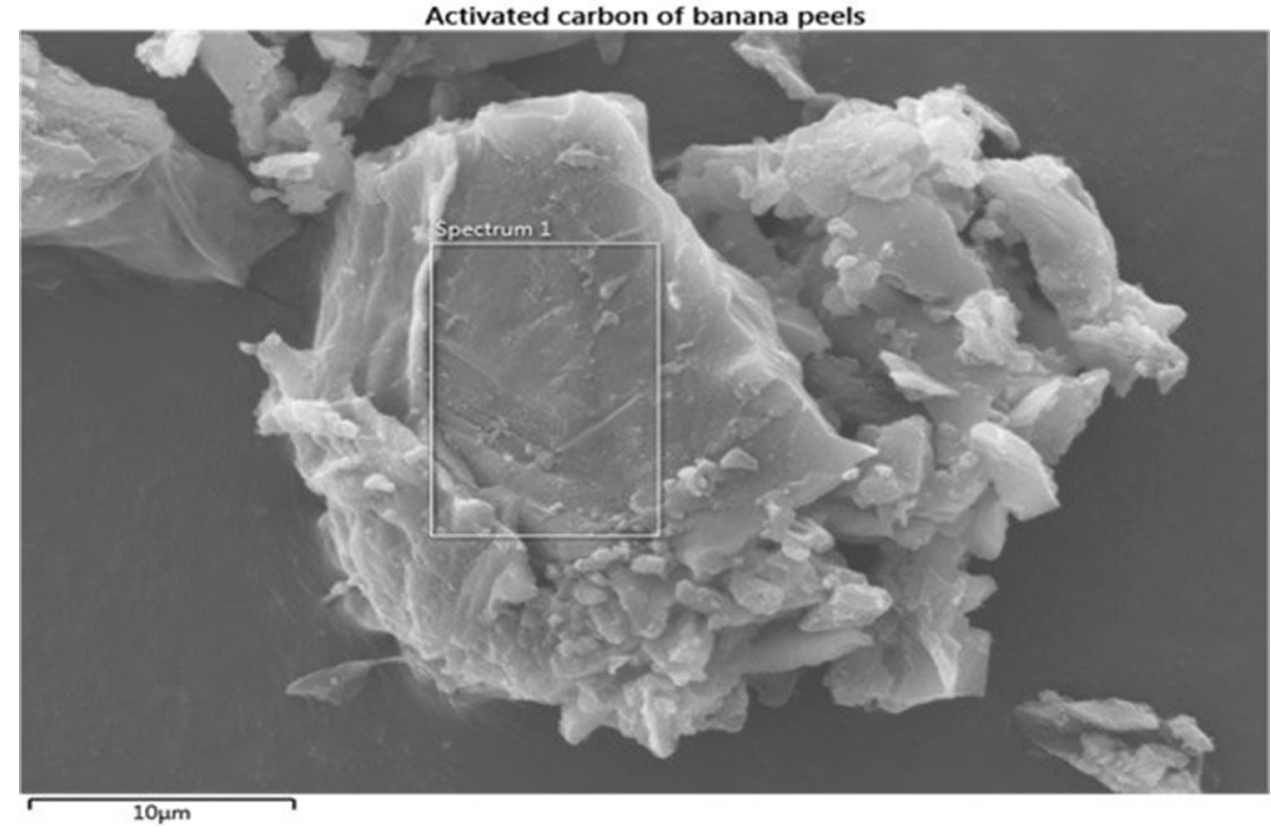

\section{Pollution removal efficiency}

Figure 7 shows results of COD and TSS removal by activated carbon made from coconut shell. COD and TSS removal by $75 \mu \mathrm{m}$ at $200 \mathrm{mg} / \mathrm{l}$ concentration was observed to be $89.15 \%$ and $92.85 \%$, respectively, while TSS removal at $500 \mathrm{mg} / \mathrm{l}$ was similar to $200 \mathrm{mg} / \mathrm{l}$; however, COD removal increased to $96.93 \%$. At $100 \mathrm{mg} / \mathrm{l}$, $85.71 \%$ of TSS removal and $87.26 \%$ COD removal was observed. By $150 \mu \mathrm{m}$ size and at $500 \mathrm{mg} / \mathrm{l}, 85.72 \%$ TSS removal and $97.64 \%$ COD removal was observed. TSS removal by $150 \mu \mathrm{m}$ at $200 \mathrm{mg} / \mathrm{l}$ concentration was to be $78.57 \%$ and COD removal was $90.8 \%$. While at $100 \mathrm{mg} / 1$ concentration by $150 \mu \mathrm{m}$ TSS removal decreased drastically, which is $50 \%$ while COD removal was to be $80.66 \%$, which can be considered as good removal. TSS and COD removal by $425 \mu \mathrm{m}$ size activated carbon at $500 \mathrm{mg} / \mathrm{l}$ concentration was $85.71 \%$ and $86.56 \%$, respectively. Similar 


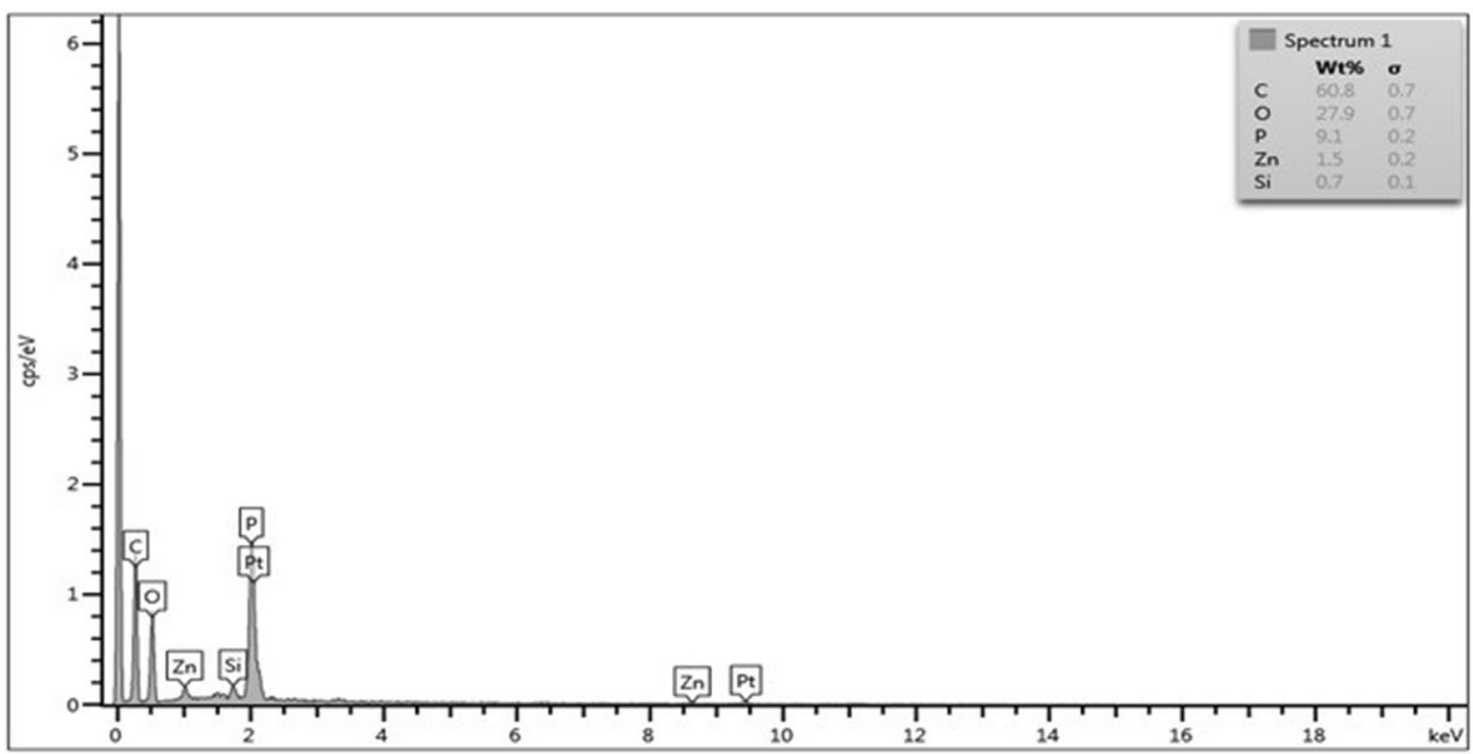

Fig. 4 Different elements observed scanning electron microscopic analysis of activated carbon made from banana peels

Fig. 5 Scanning electron microscopic analysis of activated carbon made from orange peels

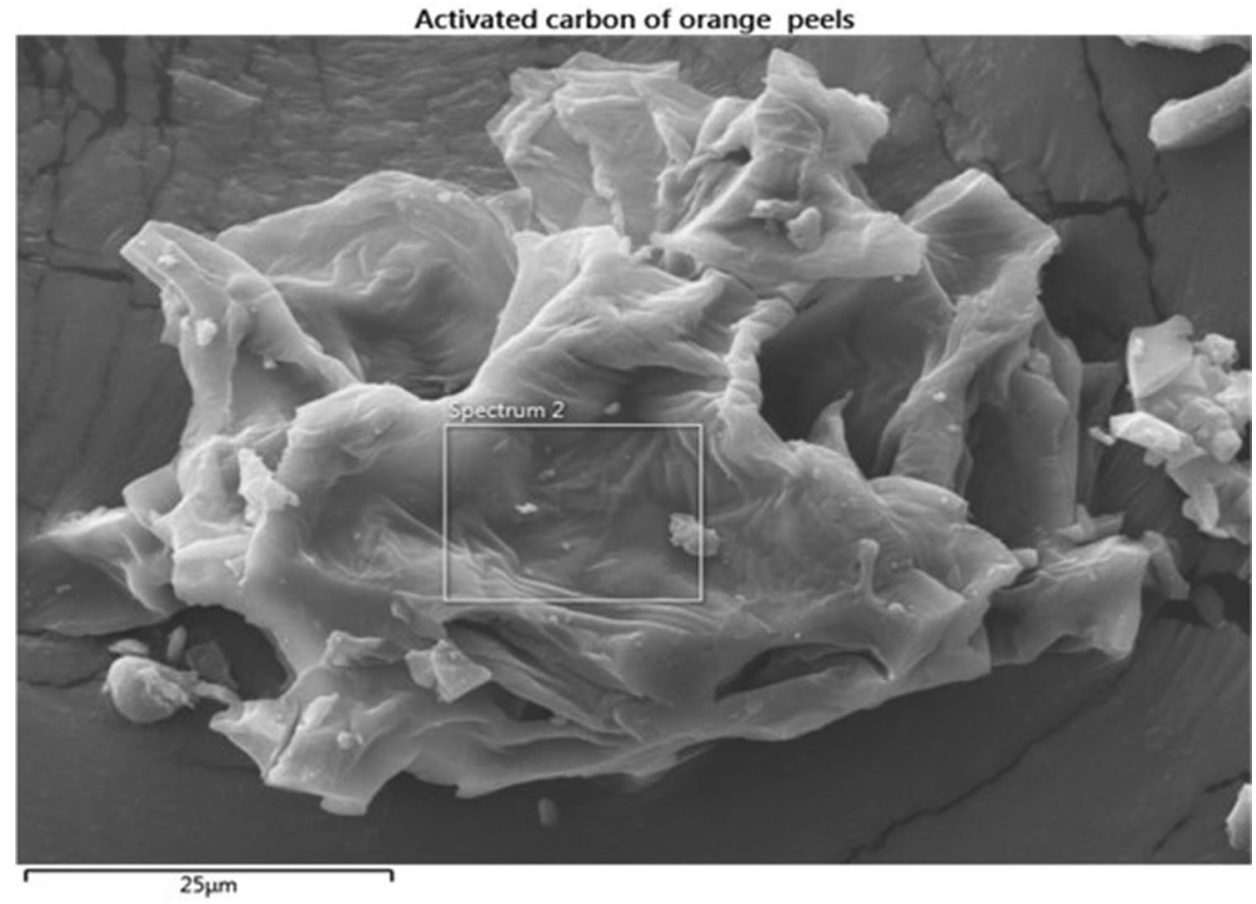

size activated carbon at $200 \mathrm{mg} / \mathrm{l}$ concentration removed $71.43 \%$ TSS and $81.36 \%$ COD, and at $100 \mathrm{mg} / 1 \mathrm{TSS}$ removal was $57.14 \%$ and COD removal was $76.41 \%$. Pollutants removal increased with the increase in activated carbon concentration and decrease in the size of activated carbon which is quite obvious. Overall, the adsorbents achieved the best result in $\mathrm{pH} 7.2-7.3$ at $500 \mathrm{mg} / 1$ concentration. The results obtained in this study are similar to the results of (Amuda and Ibrahim 2006) for coconut activated carbon.

Figure 8 shows the pollutants removal results of activated carbon made from banana peels (BPAC) at different concentration and size. As shown in Fig. 8, TSS and COD removal by $75 \mu \mathrm{m}$ at $500 \mathrm{mg} / \mathrm{l}$ concentration was observed 


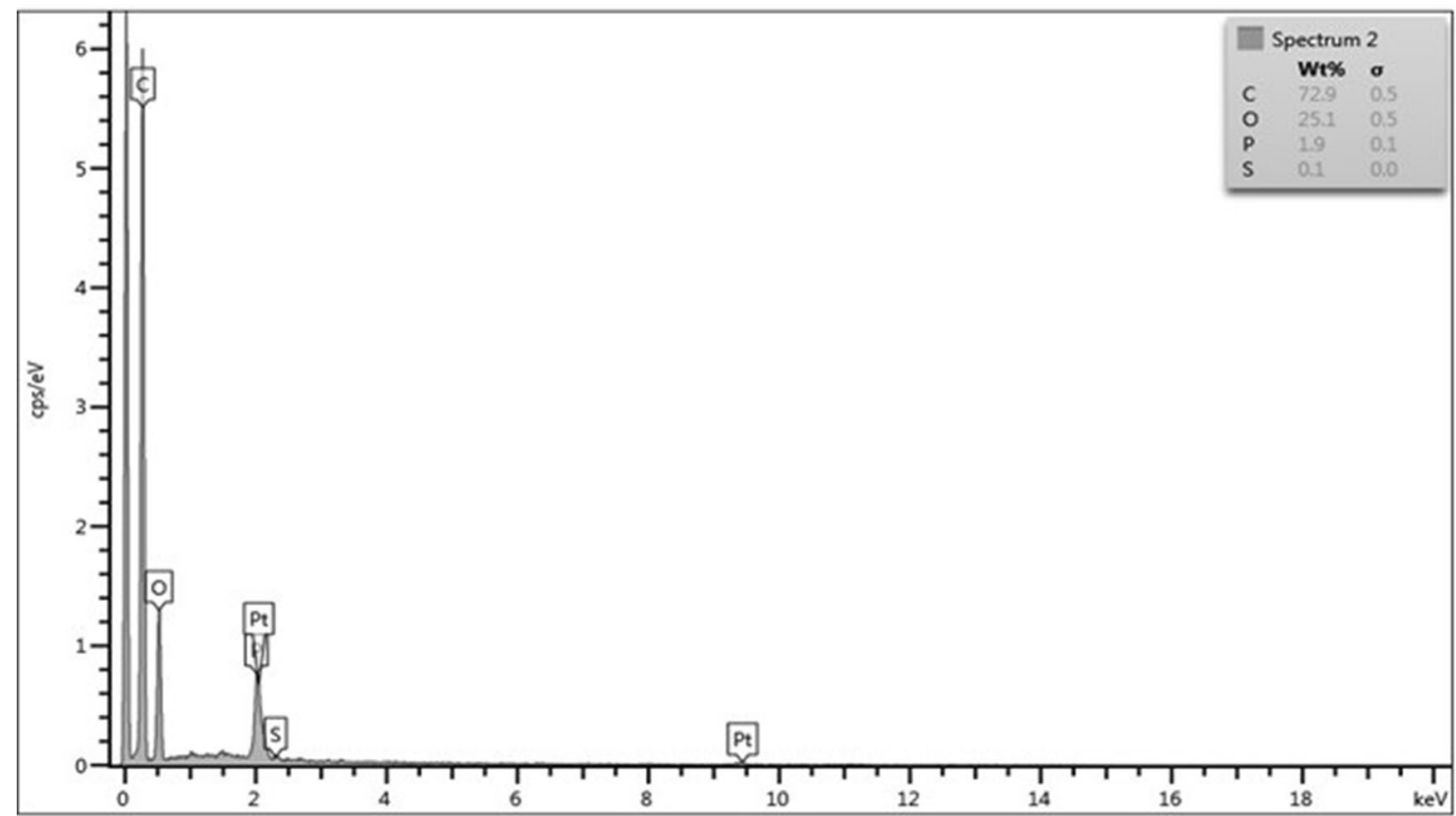

Fig. 6 Different elements observed scanning electron microscopic analysis of activated carbon made from orange peels

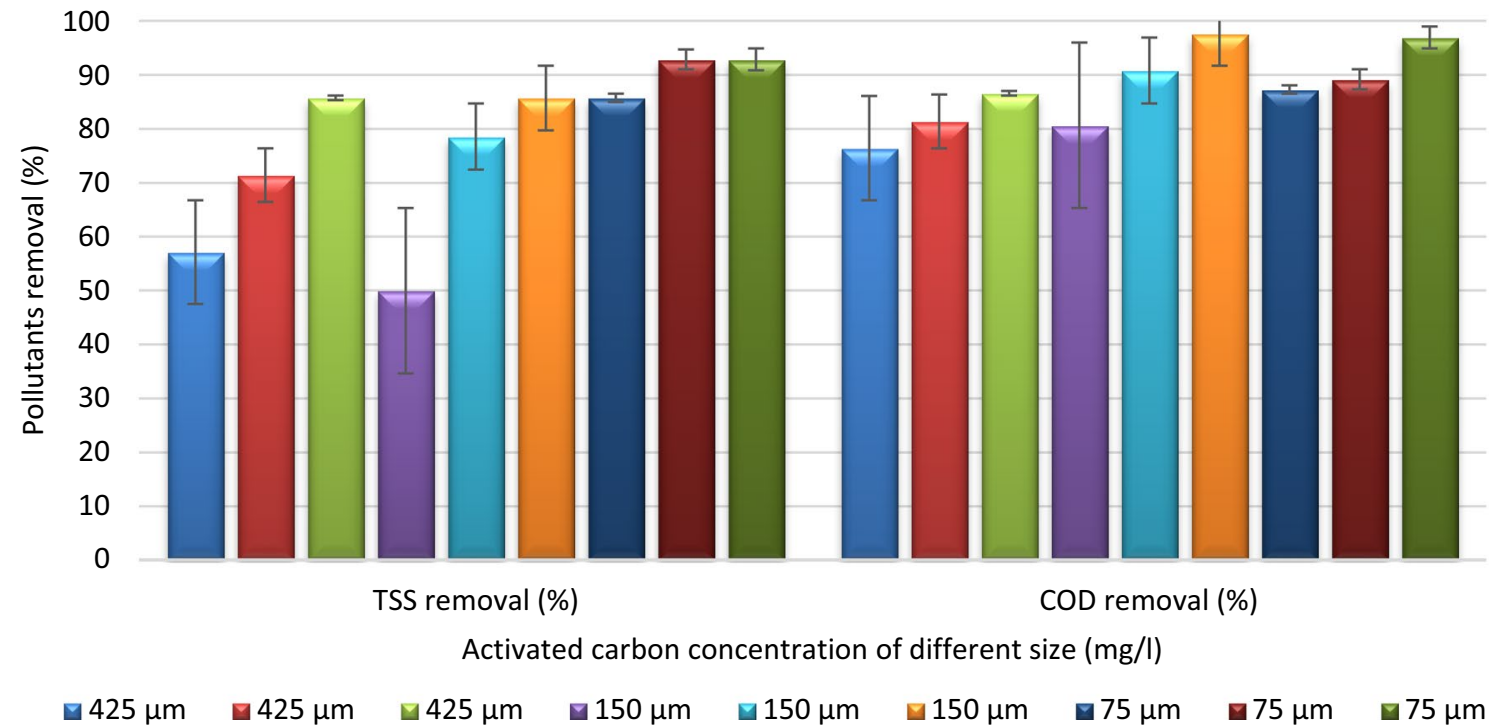

Fig. 7 Effect of coconut shell activated carbon concentration and size on removal efficiency of different pollutant

to be $100 \%$ and $96.46 \%$, respectively, while TSS removal at $200 \mathrm{mg} / \mathrm{l}$ was to be $92.85 \%$ and COD removal was to $96.22 \%$ observed. At $100 \mathrm{mg} / 1,71.43 \%$ of TSS removal and 92.21\% COD removal was observed. By $150 \mu \mathrm{m}$ size and at $500 \mathrm{mg} / \mathrm{l}, 100 \%$ TSS removal and $87.5 \%$ COD removal was observed. TSS removal by $150 \mu \mathrm{m}$ at $200 \mathrm{mg} / \mathrm{l}$ concentration was to be $85.71 \%$ and COD removal was $79 \%$. While at $100 \mathrm{mg} / \mathrm{l}$ concentration by $150 \mu \mathrm{m}$ TSS removal decreased drastically, which is $57.14 \%$ while COD removal was to be $57 \%$. TSS and COD removal by $425 \mu \mathrm{m}$ size activated carbon at $500 \mathrm{mg} / \mathrm{l}$ concentration was $100 \%$ and $68.39 \%$, respectively. Similar size activated carbon at $200 \mathrm{mg} / \mathrm{l}$ concentration removed $85.71 \%$ TSS and $71.69 \%$ COD, and at $100 \mathrm{mg} / \mathrm{l}$ TSS removal was $42.85 \%$ and COD removal was $48.11 \%$. Our results are almost similar to Ali et al. (2016), for activated carbon made from banana peels. The $\mathrm{pH}$ was in range $7-7.5$, and the removal was high in $\mathrm{pH} 7$. 


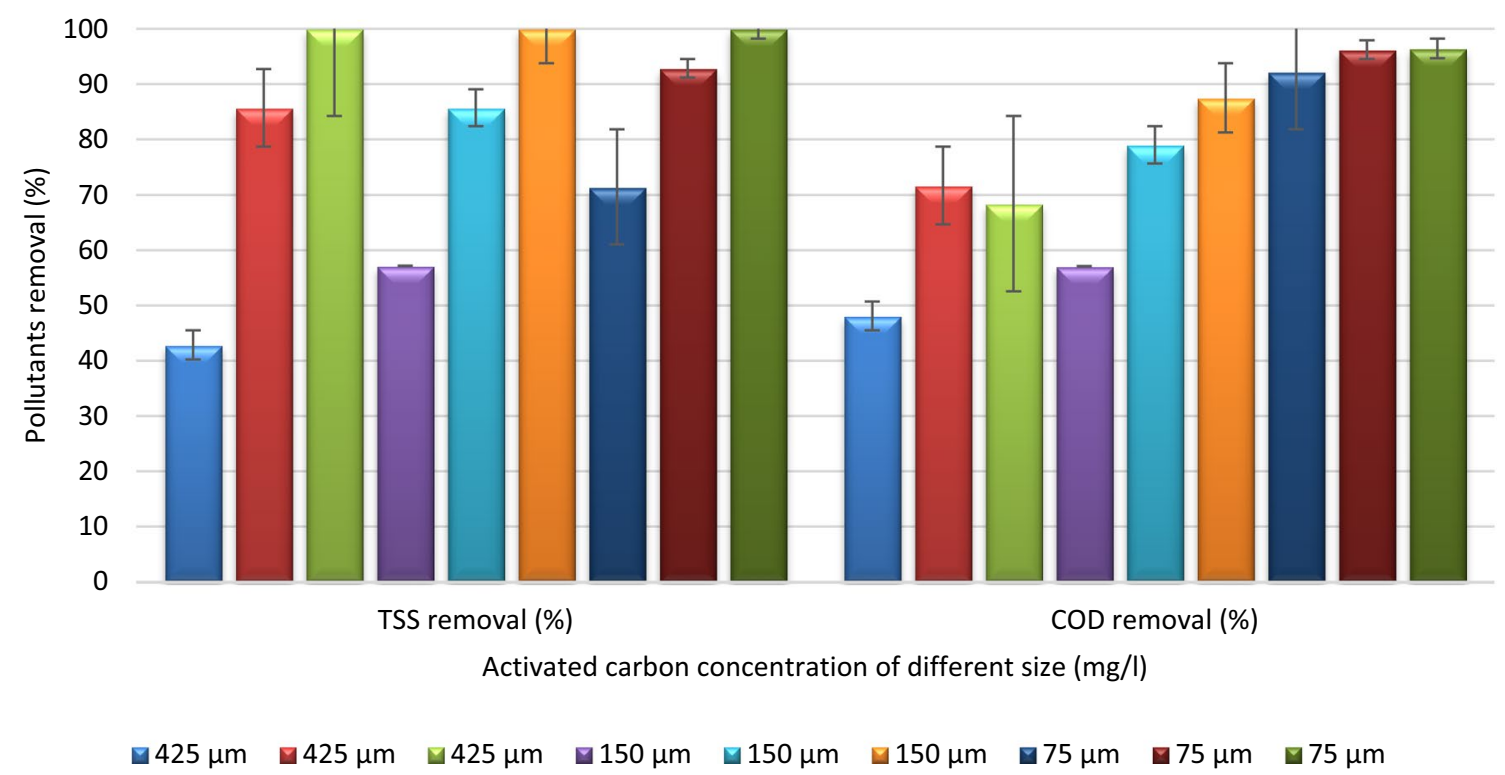

Fig. 8 Effect of banana peels activated carbon concentration and size on removal efficiency of different pollutant

Results of TSS and COD removal by activated carbon made from orange peels (OPAC) at different size and concentration are shown in Fig. 9. TSS and COD removal by $75 \mu \mathrm{m}$ at $500 \mathrm{mg} / \mathrm{l}$ concentration was observed to be $100 \%$ and $99.29 \%$, respectively, TSS removal at $200 \mathrm{mg} / \mathrm{l}$ was to be $100 \%$ and COD removal was to $97.41 \%$ observed. At $100 \mathrm{mg} / \mathrm{l}, 92.85 \%$ of TSS removal and $91.27 \%$ COD removal was observed. By $150 \mu \mathrm{m}$ size and at $500 \mathrm{mg} / \mathrm{l}, 100 \% \mathrm{TSS}$ removal and 92.22.5\% COD removal was observed. TSS removal by $150 \mu \mathrm{m}$ at $200 \mathrm{mg} / \mathrm{l}$ concentration was to be $85.71 \%$ and COD removal was $91 \%$. While at $100 \mathrm{mg} / \mathrm{l}$ concentration by $150 \mu \mathrm{m}$ TSS removal decreased drastically, which is $78.57 \%$ while COD removal was to be $89.86 \%$. TSS and COD removal by $425 \mu \mathrm{m}$ size activated carbon at $500 \mathrm{mg} / \mathrm{l}$ concentration was $64.28 \%$ and $86.55 \%$, respectively. Similar size activated carbon at $200 \mathrm{mg} / \mathrm{l}$

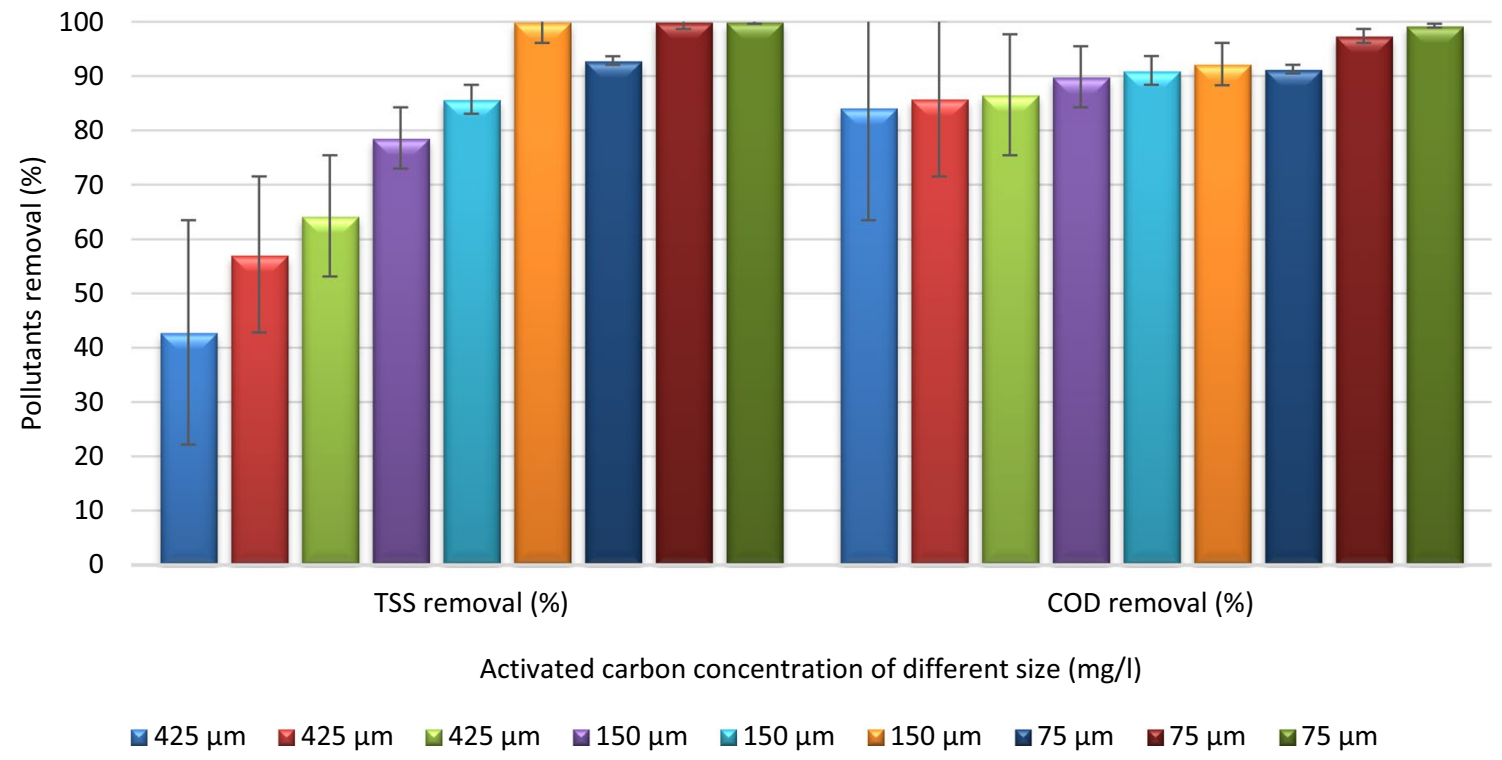

Fig. 9 Effect of orange peels activated carbon concentration and size on removal efficiency of different pollutant 
concentration removed $57.14 \%$ TSS and $85.84 \% \mathrm{COD}$, and at $100 \mathrm{mg} / \mathrm{l} \mathrm{TSS}$ removal was $42.85 \%$ and COD removal was $84.2 \%$. Results show that the best absorption was achieved in all concentrations and size at $\mathrm{pH} 7-7.5$. Furthermore, the removal percentage of TSS and COD increase with increasing the mass of activated carbon in all size of each material.

As shown in Figs. 10 and 11, overall pollutants removal in terms of COD and TSS is better in case of the activated carbon made from orange peels and the activated carbon made from coconut shells is also performing better in terms of COD removal, however, activated carbon made from banana peels at more size shows better removal of TSS than the activated carbon made from coconut shells. The reason behind the better performance of activated carbon made from orange peels could be possibly because of formation more $\mathrm{C}=\mathrm{O}$ and $\mathrm{C}-\mathrm{O}$ functional groups (Mopoung et al. 2015) due to the presence of more carbon and oxygen in orange peels activated carbon (Fig. 6). Activated carbon made from banana peels has the least carbon (Fig. 4) leads to less formation of $\mathrm{C}=\mathrm{O}$ or $\mathrm{C}-\mathrm{O}$ functional groups, which might be the reason for low COD removal.

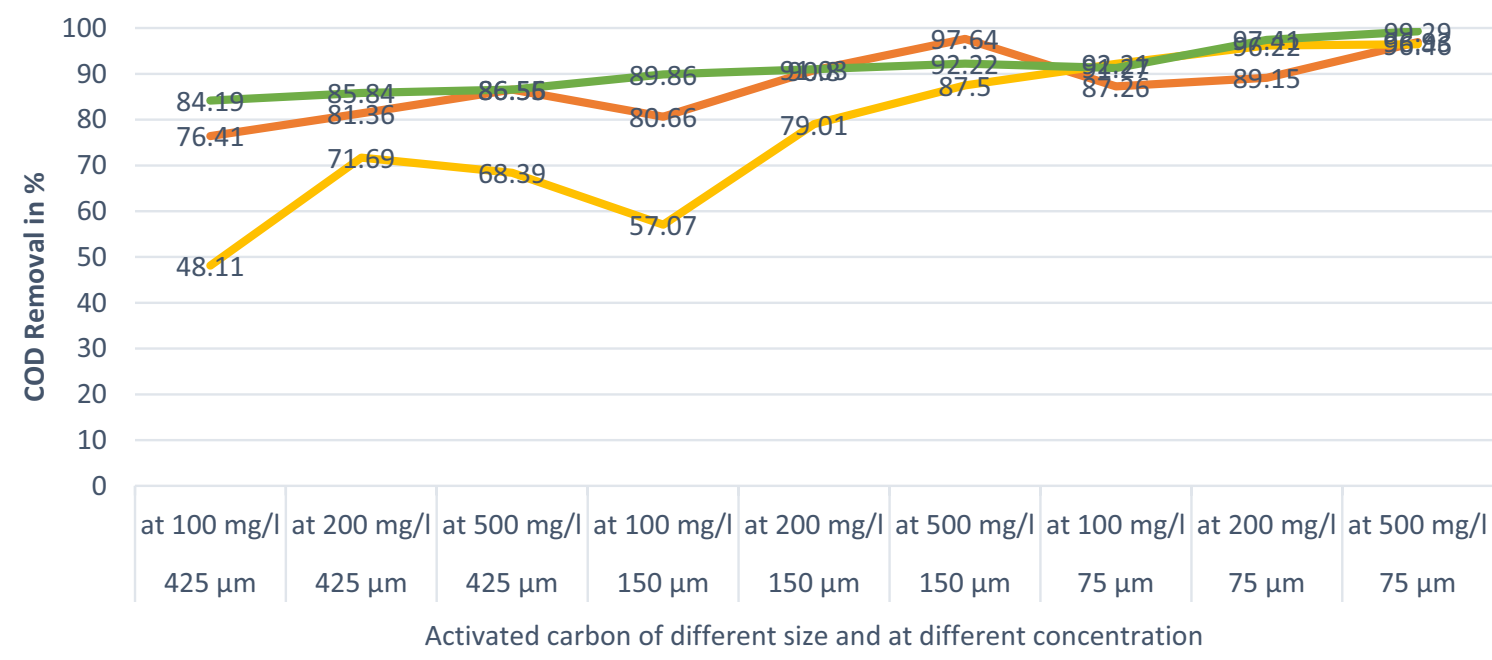

$\longrightarrow$ COD removal (\%) Coconut shell $\longrightarrow$ COD removal (\%) Banana Peels $\longrightarrow$ COD removal (\%) Orange peels

Fig. 10 Comparison of COD removal efficiency of activated carbon made from various organic materials

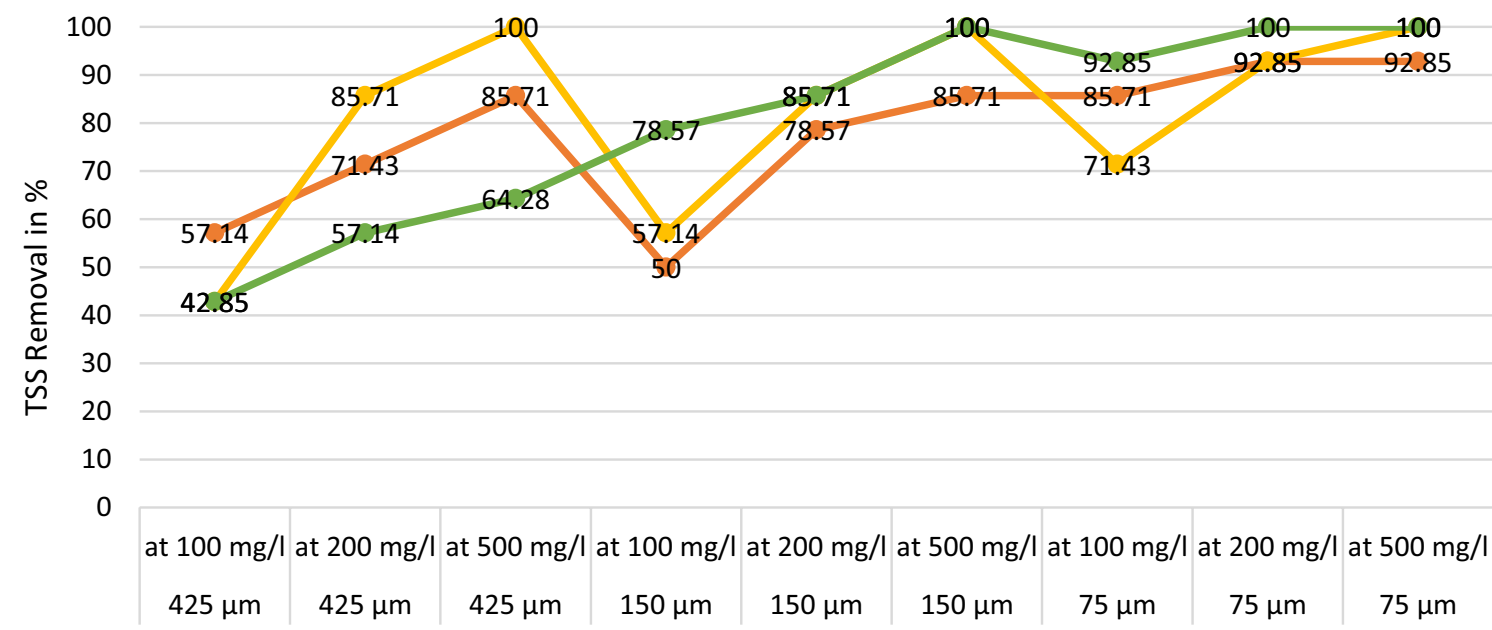

Activated carbon of different size and at different concentration

- TSS removal (\%) Coconut shell - TSS removal (\%) Banana Peels - TSS removal (\%) Orange peels

Fig. 11 Comparison of TSS removal efficiency of activated carbon made from various organic materials 


\section{Conclusions}

Activated carbon derived from coconut shell, orange peels and banana peels by chemical activation act as a good adsorbent for the removal of pollutants from the water. COD removal varies from 48 to $99 \%$ in different activated carbon at different size and concentration. TSS removal varies from 43 to $100 \%$ by different activated carbon. Small size and a higher concentration of activated carbon lead to more removal of pollutants. The highest adsorption was observed by $75 \mu \mathrm{m} \mathrm{AC}$, when the size of AC decreased the ratio of surface area/unit mass increases. Among all the experimented materials activated carbon made from orange peels performed better than other possibly due to the formation of more $\mathrm{C}-\mathrm{O}$ and $\mathrm{C}=\mathrm{O}$ functional groups (Mopoung et al. 2015). The use of low-cost organic materials to produce activated carbon for wastewater treatment will be an alternative to the expensive method, and by using organic waste to make low-cost activated carbon could reduce a load of organic waste in the landfill.

Open Access This article is licensed under a Creative Commons Attribution 4.0 International License, which permits use, sharing, adaptation, distribution and reproduction in any medium or format, as long as you give appropriate credit to the original author(s) and the source, provide a link to the Creative Commons licence, and indicate if changes were made. The images or other third party material in this article are included in the article's Creative Commons licence, unless indicated otherwise in a credit line to the material. If material is not included in the article's Creative Commons licence and your intended use is not permitted by statutory regulation or exceeds the permitted use, you will need to obtain permission directly from the copyright holder. To view a copy of this licence, visit http://creativecommons.org/licenses/by/4.0/.

\section{References}

Abdurrahman FB, Akter M, Abedin MZ (2013) Dyes removal from textile wastewater using orange peels. Int J Sci Technol Res 2(9):47-50

Ali I (2010) The quest for active carbon adsorbent substitutes: inexpensive adsorbents for toxic metal ions removal from wastewater. Sep Purif Rev 39(3-4):95-171. https://doi.org/10.1080/15422 119.2010 .527802

Ali I (2012) New Generation adsorbents for water treatment. Chem Rev 112(10):5073-5091. https://doi.org/10.1021/cr300133d

Ali I, Gupta VK (2007) Advances in water treatment by adsorption technology. Nat Protoc 1:2661. https://doi.org/10.1038/nprot 2006.370
Ali I, Asim M, Khan TA (2012) Low cost adsorbents for the removal of organic pollutants from wastewater. J Environ Manage 113:170-183

Ali A, Saeed K, Mabood F (2016) Removal of chromium (VI) from aqueous medium using chemically modified banana peels as efficient low-cost adsorbent. Alex Eng J 55(3):2933-2942

Amuda OS, Ibrahim AO (2006) Industrial wastewater treatment using natural material as adsorbent. Afr J Biotech 5(16):1483-1487

Arena N, Lee J, Clift R (2016) Life cycle assessment of activated carbon production from coconut shells. J Clean Prod 125:68-77

Ashtaputrey SD, Ashtaputrey PD (2016) J Adv Chem Sci 2(3):360-362

Association APH et al (1915) Standard methods for the examination of water and wastewater. American Public Health Association, Washington, D.C.

Bansode RR et al (2004) Pecan shell-based granular activated carbon for treatment of chemical oxygen demand (COD) in municipal wastewater. Bioresour Technol 94(2):129-135

Bhatnagar A, Sillanpää M (2010) Utilization of agro-industrial and municipal waste materials as potential adsorbents for water treatment-a review. Chem Eng J 157(2-3):277-296

Bhatnagar A, Sillanpää M, Witek-Krowiak A (2015) Agricultural waste peels as versatile biomass for water purification-a review. Chem Eng J 270:244-271

De Gisi $S$ et al (2016) Characteristics and adsorption capacities of lowcost sorbents for wastewater treatment: a review. Sustain Mater Technol 9:10-40

Foo KY, Hameed BH (2012) Preparation, characterization and evaluation of adsorptive properties of orange peel based activated carbon via microwave induced $\mathrm{K} 2 \mathrm{CO} 3$ activation. Bioresour Technol 104(suppl C):679-686

Grassi M et al (2012) Removal of emerging contaminants from water and wastewater by adsorption process BT. In: Lofrano G (ed) Emerging compounds removal from wastewater: natural and solar based treatments. Springer, Dordrecht, pp 15-37

Gupta VK, Ali I (2013a) Chapter 1-introduction. In: Gupta VK, Ali IBT-EW (eds) Elsevier, pp 1-27. Available at: http://www.scien cedirect.com/science/article/pii/B9780444593993000015

Gupta VK, Ali I (2013b) Chapter 3-water treatment for organic pollutants by adsorption technology. In: Gupta VK, Ali IBT-EW (eds) Elsevier, pp 93-116. Available at: http://www.sciencedir ect.com/science/article/pii/B9780444593993000039

Gupta VK et al (2012) Chemical treatment technologies for wastewater recycling — an overview. RSC Adv 2(16):6380-6388

Mopoung S et al (2015) Characterization and properties of activated carbon prepared from tamarind seeds by $\mathrm{KOH}$ activation for $\mathrm{Fe}(\mathrm{III})$ adsorption from aqueous solution. Sci World J 15:1-15

Yakout SM, El-deen GS (2016) Characterization of activated carbon prepared by phosphoric acid activation of olive stones. Arab J Chem 9:S1155-S1162

Publisher's Note Springer Nature remains neutral with regard to jurisdictional claims in published maps and institutional affiliations. 